This document is the Accepted Manuscript version of a Published Work that appeared in final form in Crystal Growth and Design, copyright (c) American Chemical Society after peer review and technical editing by the publisher. To access the final edited and published work see:

https://dx.doi.org/10.1021/acs.cgd.5b00218. 


\title{
Two New Adenine-based Co(II) Coordination Polymers: Synthesis, Crystal Structure, Coordination Modes and Reversible Hydrochromic Behavior
}

\author{
Iván Burneo, ${ }^{\mathrm{a}}$ Kyriakos C. Stylianou, ${ }^{\mathrm{a}}$ Sabina Rodríguez-Hermida, ${ }^{\mathrm{a}}$ Jordi Juanhuix, ${ }^{\mathrm{b}}$ Xavier Fontrodona, \\ Inhar Imaz, ${ }^{\mathrm{a}}$ and Daniel Maspoch ${ }^{\mathrm{a}, \mathrm{d}^{*}}$ \\ aICN2 - Institut Català de Nanociencia i Nanotecnologia, Campus UAB, 08193 Bellaterra (Barcelona), Spain. \\ bALBA Synchrotron, o829o Cerdanyola del Vallès, Barcelona. (Catalonia, Spain) \\ c Departament de Química, Universitat de Girona, Campus de Montilivi, E-17071 Girona, Spain \\ dInstitució Catalana de Recerca i Estudis Avançats (ICREA), o81oo Barcelona, Spain.
}

\section{Supporting Information Placeholder}

\begin{abstract}
We report the synthesis of two new $3 \mathrm{D}$ coordination polymers (CPs) based on $\mathrm{Co}(\mathrm{II})$, adenine and aromatic tetracarboxylate linkers. Adenine exhibits bidentate binding modes in both CPs, coordinating through the $\mathrm{N}_{3}$ and $\mathrm{N}_{9}$ sites in a first compact $\mathrm{CP}$ and through the more rare $\mathrm{N}_{3}$ and $\mathrm{N}_{7}$ sites in a second open, flexible and $\mathrm{H}_{2} \mathrm{O}$-responsive $\mathrm{CP}$. These differences together with an analysis of the extended coordination structures made of adenine reported in Cambridge Structural Database illustrate the rich coordination versatility of adenine as a building block for CPs. Although the latter $\mathrm{CP}$ is non-porous to $\mathrm{N}_{2}$ or $\mathrm{CO}_{2}$, it shows a reversible and detectable colour change from pink to purple, and vice versa, upon hydration and dehydration, respectively.
\end{abstract}

\section{INTRODUCTION}

Metal-Organic Frameworks (MOFs) or porous Coordination Polymers (CPs) are among the most attractive porous materials today, owing to their potential for applications such as gas storage; ${ }^{1}$ separation; ${ }^{2}$ catalysis; 3 molecular sensing; 4 adsorption for heat-pump processes; 5 contaminant removal; 6 contrast agents; 7 and drug delivery systems. ${ }^{8}$ The infinite possibilities for connecting functional organic ligands to metal ions and clusters enables the formation of countless CPs with a range of pore sizes and shapes, 9 extremely large surface areas, tailored internal surfaces, ${ }^{10}$ and flexible structures that give rise to novel phenomena such as gate-opening ${ }^{11}$ or sponge-like behavior. ${ }^{12}$ Bio-related linkers such as amino acids, peptides and nucleobases are very attracting building blocks that can be used for the formation of CPs due to their large number of oxygen and nitrogen atoms with different basicity that are available for metal coordination. ${ }^{3}$ In particular, adenine is a rigid connector with five potential coordination sites for metal binding: two imidazolate, two pyrimidinate $\mathrm{N}$ atoms and a $\mathrm{NH}_{2}$ group with basicity order of $\mathrm{N}_{9}>\mathrm{N}_{1}>\mathrm{N}_{7}>\mathrm{N}_{3}>\mathrm{N}_{6}$ (Scheme 1). It provides the widest range of neutral<smiles>Nc1ncnc2[nH]cnc12</smiles>

Scheme 1. Illustration of adenine showing the labels for the $\mathrm{N}$ binding sites.

tautomers ${ }^{14}$ and protonated forms, ${ }^{15}$ and the non-coordinated nitrogen donor sites -especially, Watson-Crick $\left(\mathrm{N}_{1}, \mathrm{~N}_{6 \mathrm{H}}\right)$ and Hoogsteen $\left(\mathrm{N}_{7}, \mathrm{~N}_{6 \mathrm{H}}\right)$ faces- can interact through hydrogen bonding. ${ }^{16}$ Its rich metal binding and $\mathrm{H}$-bonding capabilities, together with the rigidity of its molecular structure, make adenine an ideal bio-linker for constructing topologically diverse CPs. For instance, adenine has been used to build up robust porous $\mathrm{CPs}$ with applications for example in drug encapsulation and in the selective adsorption of greenhouse gasses such as $\mathrm{CO}_{2} \cdot{ }^{17,18}$ ENREF 17

Herein, we report the synthesis of two new ${ }_{3} \mathrm{D} C \mathrm{CPs}$ composed of $\mathrm{Co}(\mathrm{II})$, adenine (ade) and aromatic tetracarboxylic acids. The selected tetracarboxylic acids are 1,2,4,5-tetrakis (4-carboxyphenyl)benzene $\left(\mathrm{H}_{4} \mathrm{TCPB}\right)$ and 1,2,4,5-benzene tetracarboxylic acid $\left(\mathrm{H}_{4} \mathrm{BTeC}\right)$. $\left[\mathrm{Co}_{3}\left(\mu_{6^{-}}\right.\right.$ TCPB $\left.)\left(\mu_{4}-\mathrm{H}_{2} \text { TCPB)(ade) }\right)_{2}\right] \cdot \mathrm{H}_{2} \mathrm{O}(\mathbf{1})$ is based on a trinuclear $\mathrm{Co}$ (II) cluster, in which the three $\mathrm{Co}$ (II) ions are bridged by two bidentate adenine ligands through the $\mathrm{N}_{3}$ and $\mathrm{N}_{9}$ sites. $\left[\mathrm{Co}_{2}(\right.$ ade $\left.)\left(\mu_{6}-\mathrm{BTeC}\right)\left(\mu-\mathrm{H}_{2} \mathrm{O}\right)\left(\mathrm{H}_{2} \mathrm{O}\right)_{2}\right] \cdot 4\left(\mathrm{H}_{2} \mathrm{O}\right) \quad$ (2) comprises binuclear $\mathrm{Co}$ (II) clusters, which are linked by bidentate adenine linkers (through the $\mathrm{N}_{3}$ and $\mathrm{N}_{7}$ sites) forming ${ }_{1} \mathrm{D}$ $\mathrm{Co}(\mathrm{II})$-adenine chains. The orientation of TCPB in 1 results in a compact network, whereas $\mathrm{BTeC}^{4}$ - links the $\mathrm{Co}(\mathrm{II})$-adenine 
chains forming a $3_{\mathrm{D}} \mathrm{D}$ open network in $\mathbf{2}$. The structure 2 shows reversible structural transformations upon dehydration and hydration, which are accompanied by a detectable colour change from pink to purple, respectively. This colour change results from the dehydration process, which usually implies removal of coordinated $\mathrm{H}_{2} \mathrm{O}$ molecules and therefore, conversion from octahedral (2, hydrated, pink) to tetrahedral (2', dehydrated, purple) Co(II) coordination geometry (or vice versa, for the hydration process). ${ }^{19-22}$ It is found that $\mathbf{2}^{\prime}$ is non-porous to $\mathrm{N}_{2}$ or $\mathrm{CO}_{2}$. Contrariwise, $\mathrm{H}_{2} \mathrm{O}$ can diffuse within its framework and organize the well-ordered structure of $\mathbf{2}$.

\section{EXPERIMENTAL SECTION}

Materials and Characterization. Adenine $\left(\mathrm{C}_{5} \mathrm{H}_{5} \mathrm{~N}_{5}\right)$, 1,2,4,5-benzenetetracarboxylic acid $\left(\mathrm{H}_{4} \mathrm{BTeC}, \mathrm{C}_{10} \mathrm{H}_{6} \mathrm{O}_{8}\right)$, and 1,2,4,5-tetrakis(4-carboxyphenyl)benzene $\quad\left(\mathrm{H}_{4} \mathrm{TCPB}\right.$, $\mathrm{C}_{34} \mathrm{H}_{22} \mathrm{O}_{8}$ ) were purchased from Sigma-Aldrich, and cobalt(II) carbonate $\left(\mathrm{CoCO}_{3}\right)$ was procured from Alfa Aesar. The reagents were used as received. IR spectra were recorded in transmission mode at room temperature on a Bruker Tensor 27FTIR equipped with a Golden Gate diamond ATR cell. Thermogravimetric analysis (TGA) was done in oxygen $(20 \mathrm{ml} / \mathrm{min})$, on an STA 449 F1 Jupiter-Simultaneous TGADSC from NETZSCH (heating rate: $5^{\circ} \mathrm{C} / \mathrm{min}$; temperature range: 25 to $\left.500^{\circ} \mathrm{C}\right)$. UV/Vis spectra for 2 and $\mathbf{2}$ ' were collected on a Cary $4000 \mathrm{UV} /$ Vis spectrophotometer (Varian) equipped with a diffuse-reflectance accessory. Gas sorption $\left(\mathrm{CO}_{2} / 195 \mathrm{~K}\right.$ and $\left.\mathrm{N}_{2} / 77 \mathrm{~K}\right)$ measurements for 2' were performed using an AutosorbIQ (Quantachrome Instruments). FieldEmission Scanning Electron Microscopy (FE-SEM) images were collected using a Quanta 65oF Environmental Scanning Electron Microscopy (Field Emission Inc, USA). Aluminium was used as support. Powder X-ray Diffraction (PXRD) patterns were recorded at room temperature on an X'Pert PRO MPD diffractometer (PanAnalytical) using Co $\mathrm{K} \alpha(\lambda=$ $1.7902 \AA$ ) emission line.

Synthesis of $\left[\mathrm{Co}_{3}\left(\mu_{6}-\mathrm{TCPB}\right)\left(\mu_{4}-\mathrm{H}_{2} \mathrm{TCPB}\right)(\text { ade })_{2}\right] \cdot \mathrm{H}_{2} \mathrm{O}(\mathbf{1})$. An aqueous solution $(6 \mathrm{~mL})$ of adenine $(5 \mathrm{mg}, 0.04 \mathrm{mmol})$, $\mathrm{H}_{4}$ TCPB (10 mg, $0.02 \mathrm{mmol}$ ) and $\mathrm{CoCO}_{3}(10 \mathrm{mg}$, o.08 mmol) was placed in a $12 \mathrm{~mL}$ scintillation vial and heated at $100{ }^{\circ} \mathrm{C}$ for $48 \mathrm{~h}$. After slow cooling to room temperature during $6 \mathrm{~h}$, 1 was obtained as pink crystals, which were filtered and airdried (48\% yield). Elemental analysis, calculated (\%): C: 59.4, $\mathrm{H} 3.2$ and N: 8.9; found: C: 59.0, H: 3.1 and N: 8.7. FT-IR ( $\mathrm{KBr}$, cm-1): 3355(m); 1680(m); 1661(m); 1608(s); $1583(\mathrm{~s}) ; 1406(\mathrm{sbr})$.

Synthesis of $\left(\left[\mathrm{Co}_{2}(\right.\right.$ ade $\left.)\left(\mu_{6}-\mathrm{BTeC}\right)\left(\mu-\mathrm{H}_{2} \mathrm{O}\right)\left(\mathrm{H}_{2} \mathrm{O}\right)_{2}\right] \cdot 4\left(\mathrm{H}_{2} \mathrm{O}\right)$ (2). A mixture of adenine (5 mg, $0.04 \mathrm{mmol}), \mathrm{H}_{4} \mathrm{BTeC}$ (10 mg, $0.04 \mathrm{mmol})$ and $\mathrm{CoCO}_{3}(10 \mathrm{mg}, 0.08 \mathrm{mmol})$ in water $(6 \mathrm{~mL})$ was placed in a $12 \mathrm{~mL}$ scintillation vial and heated at $100{ }^{\circ} \mathrm{C}$ for $48 \mathrm{~h}$. After slow cooling to room temperature during $6 \mathrm{~h}$, pink crystals of $\mathbf{2}$ were obtained, filtered and air-dried $(25 \%$ yield). Elemental analysis, calculated (\%): C: $28.6, \mathrm{H}: 3.4, \mathrm{~N}$ : 11.1; found: $\mathrm{C}$ : $28.5, \mathrm{H}: 3.3, \mathrm{~N}$ : 11.3. FT-IR (KBr, cm-1): 3300(sbr); 1682(m); 1593(s); 1490(s); 1379(sbr).

Crystallography. Crystallographic data for 1 was collected at $100 \mathrm{~K}$ at XALOC beamline at ALBA synchrotron ${ }^{23}$ $(\lambda=0.79474 \AA)$. Data were indexed, integrated and scaled using the $\mathrm{XDS}^{24}$ and iMOSFLM $^{25}$ programs. Absorption corrections were not applied. Single crystal X-Ray diffraction for 2 was collected at $298 \mathrm{~K}$ on a Bruker AXS SMART Apex diffractometer using graphite monochromated Mo-K $\alpha$ radiation $(\lambda=0.71073 \AA)$ and were corrected for Lorentz and polarisation effects. The frames were integrated with the Bruker SAINT ${ }^{26}$ software package. Absorption corrections were applied using the program SADABS ${ }^{27}$ giving max./min. transmission factors of 1.00o/0.635. Both structures were solved by direct methods and subsequently refined by correction of $\mathrm{F}^{2}$ against all reflections, using SHELXS2013 ${ }^{28}$ and SHELXL2013 $3^{29}$ within the WinGX package. $3^{\circ}$ All nonhydrogen atoms were refined with anisotropic thermal parameters by full-matrix least-squares calculations on $\mathrm{F}^{2}$ using the program SHELXL2013. Hydrogen atoms were inserted at calculated positions and constrained with isotropic thermal parameters, except for the hydrogen atoms of $\mathrm{N}-\mathrm{H}$ and $-\mathrm{NH}_{2}$ groups and the water molecules in 2 . The hydrogen atoms of the adenine moiety and the water molecules were located from difference Fourier maps, fixed and isotropically refined. By contrary, in the crystal structure of $\mathbf{1}$, the disorder associated with the oxygen atoms of the four crystallization water molecules hindered the localization of their hydrogen atoms. In $\mathbf{1}$, seven distorted atoms were found (one Co, five oxygen carboxylic atoms and one carbon) and the position of the atoms in adenine moiety was fixed and refined using DELU, EADP and SIMU instructions. Several reflections, for which I(obs) and I(calc) were differing more than 10 times SigmaW, were removed from the refinement. On the other hand, the alerts observed during the checkcif can be explained by the quality of the crystal. The best crystal was chosen and attempts to obtain better data were unsuccessful. Although the diffraction experiments proceeded at $100 \mathrm{~K}$ under synchrotron radiation, the disorder of the structure could not be reduced and the values of the weighted $\mathrm{R}$ factor and $\mathrm{wR}_{2}$ remained high. Moreover, the short Inter D...A contact between the $\mathrm{O}_{5} \mathrm{~A}$... O6 $\mathrm{B}$ and $\mathrm{O}_{5} \mathrm{~A}$... O6A atoms can be explained by the disorder associated with these $\mathrm{O}_{5}$ and O6. Crystal data of 1 and 2 and structure refinement data are listed in Table 1 . Main bond distances and angles, and $\mathrm{H}$-bond parameters of $\mathbf{1}$ and $\mathbf{2}$ are listed in Tables $\mathrm{S}_{1}-\mathrm{S}_{4}(\mathrm{ESI}+$ ).

Table 1. Crystal and Structure Refinement data.

\begin{tabular}{|c|c|c|}
\hline Compound & 1 & 2 \\
\hline Empirical formula & $\mathrm{C}_{78} \mathrm{H}_{48} \mathrm{~N}_{10} \mathrm{O}_{24} \mathrm{Co}_{3}$ & $\mathrm{C}_{15} \mathrm{H}_{21} \mathrm{~N}_{5} \mathrm{O}_{15} \mathrm{Co}_{2}$ \\
\hline Formula weight & 1686.05 & 629.23 \\
\hline Crystal system & Monoclinic & Monoclinic \\
\hline Space group & $\mathrm{P}_{2} / \mathrm{n}$ & $\mathrm{P}_{2} / \mathrm{n}$ \\
\hline CCDC ref & 1043962 & 1043963 \\
\hline \multicolumn{3}{|c|}{ Unit cell dimensions } \\
\hline a $(\AA)$ & $9 \cdot 77$ & 9.47 \\
\hline b $(\AA)$ & 17.33 & 12.58 \\
\hline c $(\AA)$ & 22.71 & 18.98 \\
\hline$\beta$ (deg) & 100.9 & $93 \cdot 5$ \\
\hline$V\left(\AA \AA^{3}\right)$ & 3775.8 & 2256.0 \\
\hline $\mathrm{Z}$ & 2 & 4 \\
\hline F (ooo) & 1710 & 1280 \\
\hline$\theta$ range $\left(^{\circ}\right)$ & $1.66-33.82$ & $1.94-28.39$ \\
\hline Ind refln ( $\left.\mathrm{R}_{\text {int }}\right)$ & 9365 (o.0349) & $5531(0.1063)$ \\
\hline Final $\mathrm{R}$ indices & $\mathrm{R}_{1}=0.1272$ & $\mathrm{R}_{1}=0.0573$ \\
\hline$[\mathrm{I}>2 \sigma(\mathrm{I})]$ & $\mathrm{wR2}=0.455^{\circ}$ & $\mathrm{wR2}=0.1220$ \\
\hline
\end{tabular}


a.

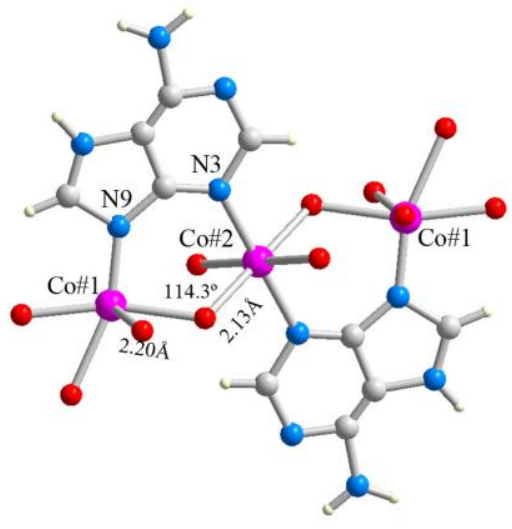

c.

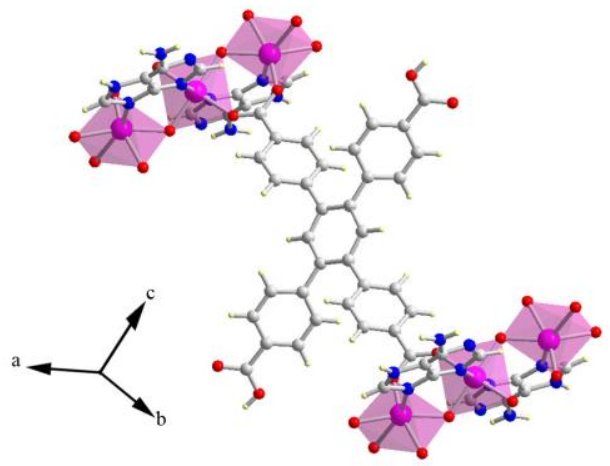

b.

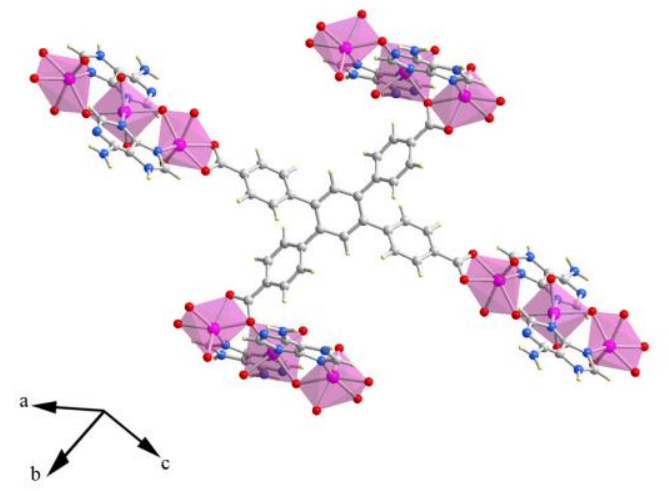

d.

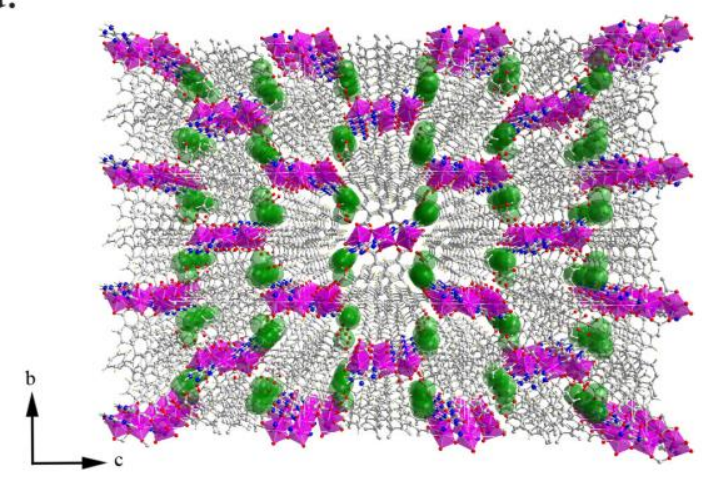

Figure 1. (a) Illustration of the Co\#1-Co\#2-Co\#1 basic unit in 1, showing that Co\#1 and Co\#2 ions are linked by two bidentate adenine ligands. The pink octahedra represents the coordination environment of $\mathrm{Co}$ (II) ions. (b) Illustration showing the TCPB ${ }^{4-}$ linker that binds to six $\mathrm{Co}(\mathrm{II})$ centers and connects four Co\#1-Co\#2-Co\#1 clusters. (c) Illustration showing the $\mathrm{H}_{2} \mathrm{TCPB}^{2-}$ linker that binds to four $\mathrm{Co}$ (II) centers and connects two Co\#1-Co\#2-Co\#1 clusters. (d) Perspective view of the overall 3D compact framework of 1. Colour code: O: red; N: blue; H: pale yellow; C: grey; Co: pink; and water molecules: green.

\section{RESULT AND DISCUSSION}

Synthesis and Characterization of 1 and 2. Hydrothermal reactions between $\mathrm{CoCO}_{3}$, a basic metal salt source, adenine and $\mathrm{H}_{4} \mathrm{TCPB}$ or $\mathrm{H}_{4} \mathrm{BTeC}$ in water at $100^{\circ} \mathrm{C}$ for $48 \mathrm{~h}$ produced pink block-type crystals of $\mathbf{1}$ and $\mathbf{2}$, respectively. The simulated (derived from the single crystal structure of $\mathbf{1}$ and 2, vide infra) and experimental powder Xray diffraction (PXRD) patterns were consistent (Figure $\mathrm{S}_{1}$, ESI $\dagger$ ); confirming that $\mathbf{1}$ and $\mathbf{2}$ can be obtained as pure phases (as also evidenced by elemental analysis and SEM; Figure S2, ESI $\dagger$ ). Thermogravimetric analysis (TGA) of 1 revealed multiple weight losses in the range of $315-500{ }^{\circ} \mathrm{C}$, corresponding to its decomposition (Figure $\mathrm{S}_{4}$; ESI†). In 2, the TGA profile indicates a weight loss of $17.5 \%$ (from 25 to $\left.150{ }^{\circ} \mathrm{C}\right)$, which we attributed to the loss of the six guest and terminal coordinated $\mathrm{H}_{2} \mathrm{O}$ molecules (calculated: $17.2 \%$; Figure 5b). Decomposition of 2 starts at $300{ }^{\circ} \mathrm{C}$, probably immediately after the loss of the remaining $\mu-\mathrm{H}_{2} \mathrm{O}$ molecule (essential to maintain the dinuclear cluster, vide infra), and occurs in a single step, forming $\mathrm{CoO}$.

Crystal Structure Analysis of 1. In 1, there are two crystallographically independent $\mathrm{Co}$ (II) ions, which are both octahedrally coordinated forming a trinuclear cluster in the order of Co\#1-Co\#2-Co\#1 (Figure 1a). The Co\#1-Co\#2 distance within this cluster is $3.62 \AA$. Co\#1 is $\left(\mathrm{NO}_{5}\right)$ - octahedrally coordinated to the imidazolate $\mathrm{N}_{9}$ atom of adenine and five carboxylate $\mathrm{O}$ atoms from three adjacent TCPB ligands. Co\#2 is $\left(\mathrm{N}_{2} \mathrm{O}_{4}\right)$-octahedrally coordinated to the pyrimidinate $\mathrm{N}_{3}$ atoms of two adjacent adenine ligands and to four neighboring TCPB linkers. Here, adenine is acting as a bridging ligand, linking the two Co\#1 and Co\#2 ions within the trinuclear cluster through the $\mathrm{N}_{3}$ and $\mathrm{N}_{9}$ sites (Figure 1a). The three-dimensional structure of $\mathbf{1}$ is constructed by the connection of these clusters through TCPB linkers. Within the asymmetric unit of $\mathbf{1}$, there are two distinct TCPB linkers: i) a TCBP4- linker fully deprotonated that binds to six $\mathrm{Co}(\mathrm{II})$ ions with $\kappa_{2} \mathrm{O}, \mathrm{O}^{\prime}$ and $\mu-\kappa_{2} \mathrm{O}, \mathrm{O}^{\prime}: \kappa \mathrm{O}^{\prime}$ coordination modes (Figure $1 \mathrm{~b}$; Figure $\mathrm{S}_{5}, \mathrm{ESI}+$ ); and ii) a $\mathrm{H}_{2} \mathrm{TCPB}^{2-}$ linker partially protonated, in which two parabenzoate groups coordinate to four $\mathrm{Co}(\mathrm{II})$ ions with a $\mu-\kappa \mathrm{O}$; $\kappa \mathrm{O}^{\prime}$ coordination mode (Figure $1 \mathrm{c}$; Figure $\mathrm{S}_{5}$, ESI + ) and the other two protonated para-benzoate groups are hydrogen bonded with $\mathrm{H}_{2} \mathrm{O}$ molecules, affording a compact ${ }_{3} \mathrm{D}$ structure (Figure 1d).

In order to better understand the crystal structure of $\mathbf{1}$, a topological analysis was performed using TOPOS ${ }^{31}$ program. As a result, 1 shows a $3 \mathrm{D}$ binodal 4,6 -c net where each Co\#1Co\#2-Co\#1 cluster is connected to ten other clusters through 6 TCPB ligands with distances in the range of $15 \cdot 77-26.63 \AA$. Overall, this MOF shows a new topology with the point symbol $\left\{4^{\wedge} 4.6^{\wedge} 10.8\right\}\left\{4^{\wedge} 4.6^{\wedge} 2\right\}$ (Figure $2 \mathrm{a}$ ). 
a.

$\mathrm{TD} 10=3895$

Point symbol net: $\left\{4^{\wedge} 4.6^{\wedge} 10.8\right\}\left\{4^{\wedge} 4.6^{\wedge} 2\right\}$

$4,6-\mathrm{c}$ net

structure 1 b.

Topological type: fsc

4,6-c net
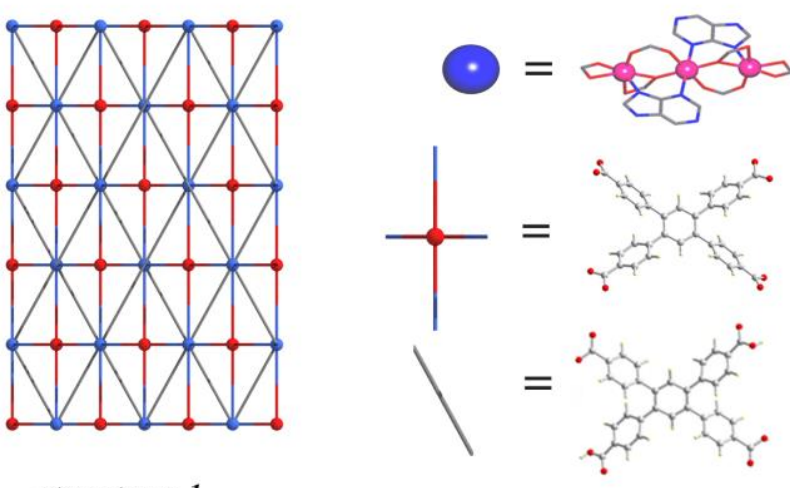

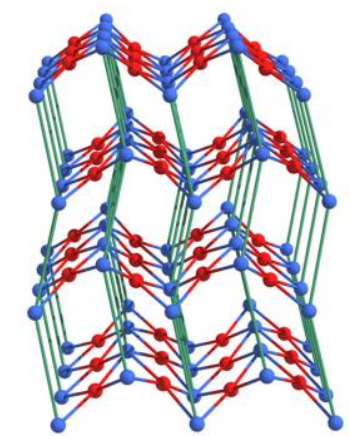

structure 2

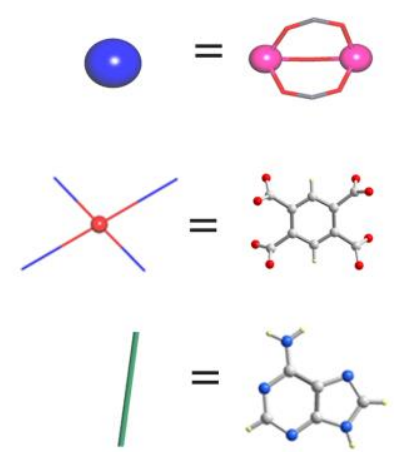

Figure 2. Topological illustration of $\mathbf{1}(\mathrm{a})$ and $\mathbf{2}$ (b), and the simplifications used in the analysis with TOPOS program. Note that a new topology was found for $\mathbf{1}$.

Crystal Structure Analysis of 2. The basic unit of 2 is a binuclear Co\#1-Co\#2 cluster, in which both $\mathrm{Co}(\mathrm{II})$ ions exhibit $\left(\mathrm{NO}_{5}\right)$-octahedral geometries, although with different coordination environments (Figure 3a). Co\#1 is coordinated to the pyrimidinate $\mathrm{N}_{3}$ atom of adenine, four carboxylate $\mathrm{O}$ atoms from four adjacent $\mathrm{BTeC} 4^{-}$ligands, and one $\mu-\mathrm{H}_{2} \mathrm{O}$ molecule bridging both $\mathrm{Co}(\mathrm{II})$ ions. In contrast, Co\#2 is coordinated to the imidazolate $\mathrm{N}_{7}$ atom of adenine, two carboxylate $\mathrm{O}$ atoms from $\mathrm{BTeC}^{4-}$, two terminal $\mathrm{H}_{2} \mathrm{O}$ molecules and the $\mu-\mathrm{H}_{2} \mathrm{O}$ bridge (Figure 3a). The Co\#1-Co\#2 distance within this cluster unit is $3.63 \AA$. Comparison of the bond lengths for Co\#1- $\mu-\mathrm{H}_{2} \mathrm{O}$ and Co\#2- $\mu-\mathrm{H}_{2} \mathrm{O}(2.15 \AA$ and $2.14 \AA$, respectively), and the angle between $\mathrm{Co} \# 1-\mathrm{H}_{2} \mathrm{O}-\mathrm{Co} \# 2$ (115.8ㅇ), with corresponding literature values for structures a.
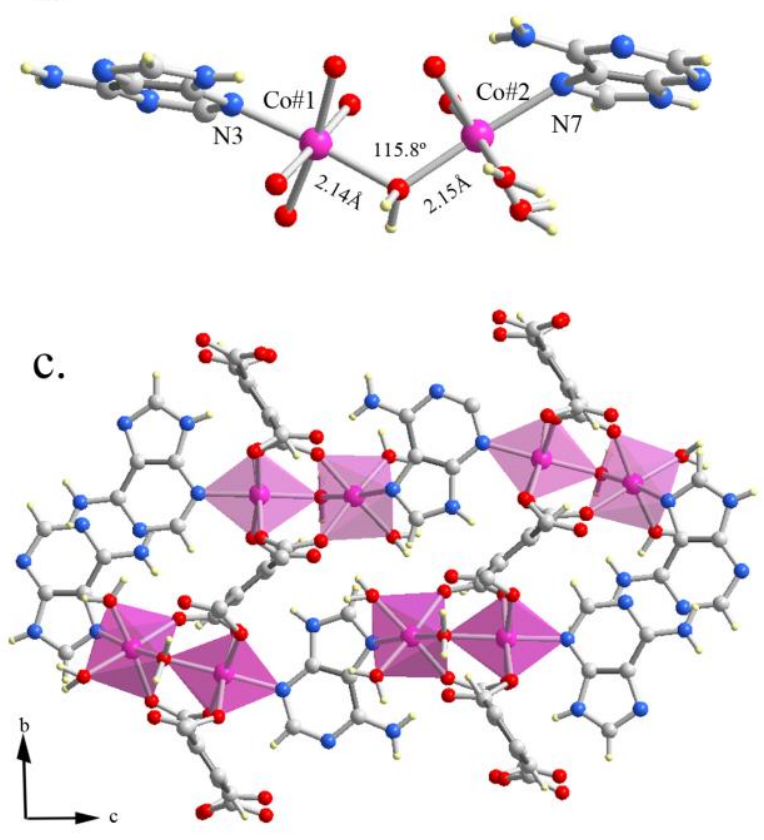

b.
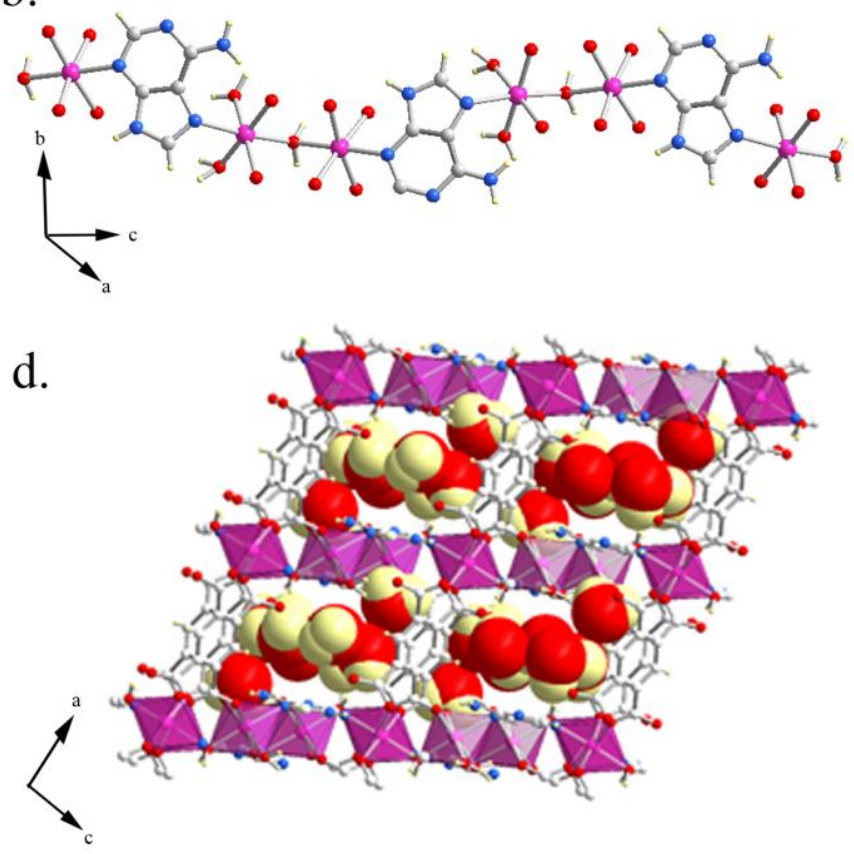

Figure 3. (a) Illustration of the Co\#1-Co\#2 unit within 2. (b) Representation of the $1 \mathrm{D}$ chains built up from connecting the Co\#1-Co\#2 units through adenine ligands. (c) Representation of the $1 \mathrm{D}$ chains linked by BTeC4- ligands (the C atoms of BTeC4are colored in dark grey) to form the $3 \mathrm{D}$ framework of 2 . The pink octahedron represent the coordination environment of $\mathrm{Co}(\mathrm{II})$ ions. (d) Illustration of 2 , showing the ${ }_{1} \mathrm{D}$ channels filled with guest $\mathrm{H}_{2} \mathrm{O}$ molecules (space filling). Color code: $\mathrm{O}$ : red; $\mathrm{N}$ : blue; H: pale yellow; C: grey; and Co: pink. 
containing the same metal M-O-M unit (CSD codes: ZALXAL, UMAGUK), ${ }^{32}, 33$ confirmed the presence of the $\mathrm{H}_{2} \mathrm{O}$ bridge (Table $\mathrm{S}_{4}$, ESI + ). Adenine linkers bridge the Co\#1Co\#2 clusters involving the $\mathrm{N}_{3}$ and $\mathrm{N}_{7}$ sites, thus forming ${ }_{1} \mathrm{D}$ chains running along the $c$-axis (Figure $3 \mathrm{~b}$ ).

The use of the tetracarboxylate $\mathrm{BTeC}^{4-}$ linkers was found to be prolific for the expansion of $\mathbf{2}$ in three dimensions, as each $\mathrm{BTeC}^{4-}$ links four neighboring chains (one from each carboxylate site) (Figure 3c; Figure S6, ESI $\dagger$ ). In particular, each $\mathrm{BTeC}_{4-}$ binds to six $\mathrm{Co}$ (II) centers in two coordination modes: a monodentate $\kappa \mathrm{O}$ mode, in binding Co\#1 from the carboxylate positions 1 and 4 ; and a bidentate $\mu-\kappa \mathrm{O}$ : $\kappa \mathrm{O}^{\prime}$ mode, in bridging Co\#1 and Co\#2 from the carboxylate positions 2 and 5 . Framework 2 generates regular $1 \mathrm{D}$ channels (5.3 x $4.8 \AA$; 609.1 $\AA 3$; $27 \%$ of void space in unit cell) 34 along the $b$-axis (Figure $\mathrm{S}_{7}, \mathrm{ESI}+$ ). Figure $3 \mathrm{~d}$ shows that the channels accommodate four guest $\mathrm{H}_{2} \mathrm{O}$ molecules per formula unit. Importantly, the amino $-\mathrm{NH}_{2}$ and the imidazolate $-\mathrm{NH}$ of adenine that reside within the channel establish $\mathrm{H}$-bond interactions with water molecules and oxygen atoms of the carboxylic groups. Moreover, the $\mathrm{N}_{1}$ pyridiminate nitrogen atom acts as acceptor of $\mathrm{H}$-bond interactions established with water molecules (see all $\mathrm{H}$ bonds in Table $\mathrm{S}_{5}$, ESI†). The theoretical pore volume of 2 calculated from the crystallographic structure after removing the guest $\mathrm{H}_{2} \mathrm{O}$ molecules is $0.176 \mathrm{~cm}^{3} \mathrm{~g}^{-1}$. In this case, the topological analysis showed that 2 presents the known fsc net (Figure 2b).

Adenine in CPs. An analysis of extended structures containing adenine and transition metal ions obtained from the Cambridge Structural Database (CSD; Allen, 2002) illustrates the rich coordination modes that can adopt adenine for constructing CPs. From this study, we found that adenine can act as a simple monodentate ligand, mainly through the $\mathrm{N}_{3}$ or $\mathrm{N}_{9}$ site.35-37 Examples of these coordination modes were observed by García-Terán et al. in $1 \mathrm{D} \mathrm{Zn}(\mathrm{II})$ - and $\mathrm{Cu}(\mathrm{II})$-oxalate chains, in which adenine coordinates these metal ions only through the $\mathrm{N}_{3}{ }^{35}$ and the $\mathrm{N}_{9}{ }^{37}$ site, respectively (Figures $4 \mathrm{a}$ and $4 \mathrm{~b}$ ).

Adenine can also act as a bidentate ligand; having here a wide variety of combinations depending on the $\mathrm{N}$ sites that participate in the metal binding. Overall, we have detected that adenine can coordinate to two metal ions through the: $i)$ $\left[\mathrm{N}_{3}, \mathrm{~N}_{9}\right] ; 38,39$ ii) $\left[\mathrm{N}_{7}, \mathrm{~N}_{9}\right] ; 39-42$ iii) $\left[\mathrm{N}_{1}, \mathrm{~N}_{9}\right] ; 43$ iv) $\left[\mathrm{N}_{1}, \mathrm{~N}_{7}\right] ; 39$ and v) $\left[\mathrm{N}_{3}, \mathrm{~N}_{7}\right]$ (in 2) sites. An example of the first coordination mode was reported by Stylianou et al. in $\left[\mathrm{Ni}_{3}(\mathrm{PZDC})_{2}(\text { ade })_{2}\left(\mathrm{H}_{2} \mathrm{O}\right)_{4}\right]\left(\mathrm{H}_{2} \mathrm{O}\right)_{1.5}$ (where PZDC = 3,5pyrazoledicarboxylate).$^{38}$ In this structure, adenine participates in the formation of $\mathrm{Ni}$ (II) dimers by bridging two $\mathrm{Ni}$ (II) ions through the $\mathrm{N}_{3}$ and $\mathrm{N}_{9}$ sites (Figure 4c). These $\mathrm{Ni}(\mathrm{II})$ units are then connected through PZDC linkers, forming chains that are $3 \mathrm{D}$ hydrogen-bonded. The second coordination mode was observed in [Zn(ade)(INT)].DMF (where INT = isonictinate; DMF = dimethylformamide). $4^{\circ}$ In this compound, adenine connects $\mathrm{Zn}$ (II) ions through the $\mathrm{N}_{7}$ and $\mathrm{N}_{9}$ sites (Figure $4 \mathrm{~d}$ ), creating infinite $1 \mathrm{D}$ helices that are 3D linked by the INT linkers. Sanjib Das et al. described the third coordination mode in a $1 \mathrm{D} \mathrm{Cu}$ (II) $\mathrm{CP}$ with formula $\left[\mathrm{Cu}\right.$ (glycine) (ade) $\left.\left(\mathrm{NO}_{3}\right)\left(\mathrm{H}_{2} \mathrm{O}\right)\right]$. Here, adenine connects two $\mathrm{Cu}(\mathrm{II})$ ions through the $\mathrm{N}_{1}$ and $\mathrm{N}_{9}$ sites (Figure $4 \mathrm{e}$ ), creating zig-zag chains that are $3 \mathrm{D}$ hydrogen bonded. 43 An example of the last reported $\left[\mathrm{N}_{1}, \mathrm{~N}_{7}\right]$ coordination mode (Figure $4 \mathrm{f}$ ) can be found in $\left[\mathrm{Cd}\right.$ (ade) $\left.(\mathrm{IPA})\left(\mathrm{H}_{2} \mathrm{O}\right)\right]$ (where IPA = isophtalate). In this $2 \mathrm{D} C \mathrm{C}$, adenine forms chains binding $\mathrm{Cd}(\mathrm{II})$ ions through the $\mathrm{N}_{1}$ and $\mathrm{N}_{7}$ sites, which are further $2 \mathrm{D}$ connected by the IPA linkers. 39

In our reported extended structures $\mathbf{1}$ and $\mathbf{2}$, adenine also acts as a bidentate ligand coordinating to two $\mathrm{Co}$ (II) ions. In 1, adenine bridges two $\mathrm{Co}(\mathrm{II})$ ions through the $\mathrm{N}_{3}$ and $\mathrm{N}_{9}$ sites forming a trinuclear $\mathrm{Co}$ (II) cluster (Figure 4c). This coordination mode is very similar to the one observed by Stylianou et al. $3^{8}$ In contrast, adenine exhibits a rare coordination mode through the $\mathrm{N}_{3}$ and $\mathrm{N}_{7}$ sites in 2 (Figure $4 \mathrm{~g})$. To the best of our knowledge, this coordination mode was only observed in two previous discrete $\mathrm{Cu}(\mathrm{II})$-based complexes.44, 45 Through this $\left[\mathrm{N}_{3}, \mathrm{~N}_{7}\right]$ coordination mode, adenine participates in the formation of infinite $\mathrm{Co}(\mathrm{II})$ adenine chains that are $3 \mathrm{D}$ linked by $\mathrm{BTeC} 4$ - linkers.

Besides of acting as a bidentate ligand, adenine can also coordinate via more than two $\mathrm{N}$ sites. In fact, the most common coordination mode found in CPs is $\left[\mathrm{N}_{3}, \mathrm{~N}_{7}, \mathrm{~N}_{9}\right] .^{18,46-}$ 54 For example, adenine coordinates to three $\mathrm{Cu}$ (II) ions via the $\mathrm{N}_{3}, \mathrm{~N}_{7}$ and $\mathrm{N}_{9}$ sites (Figure $4 \mathrm{~h}$ ) in a porous $\mathrm{CP}$ with formula $\left[\mathrm{Cu}_{2}(\text { ade })_{2}\left(\mathrm{H}_{2} \mathrm{O}\right)_{2}\right] \cdot\left[\mathrm{Cu} \text { (oxalate) }\left(\mathrm{H}_{2} \mathrm{O}\right)\right]_{2} \cdot \sim 14 \cdot \mathrm{H}_{2} \mathrm{O} .4^{6} \mathrm{In}$ this $\mathrm{CP}$, four adenine ligands participate in the formation of a paddle wheel unit by bridging two $\mathrm{Cu}$ (II) ions through the $\mathrm{N}_{3}$ and $\mathrm{N}_{9}$ sites. These units are then connected through mononuclear entities $\left(\left[\mathrm{Cu}(\right.\right.$ oxalate $\left.\left.)\left(\mathrm{H}_{2} \mathrm{O}\right)\right]\right)$ via the $\mathrm{N}_{7}$ site. More unusual coordination modes for adenine are $\left[\mathrm{N}_{1}, \mathrm{~N}_{6}\right.$, $\left.\mathrm{N}_{9}\right]$ and $\left[\mathrm{N}_{3}, \mathrm{~N}_{6}, \mathrm{~N}_{9}\right]$. An example of the $\left[\mathrm{N}_{1}, \mathrm{~N}_{6}, \mathrm{~N}_{9}\right]$ coordination mode can be found in $\left[\left(\mathrm{CH}_{3} \mathrm{Hg}\right)_{2}\right.$ (ade) $] \cdot \mathrm{EtOH}$ (Figure 4i). 54 In this structure, two $\mathrm{CH}_{3} \mathrm{Hg}^{+}$ions are coordinated through the $\mathrm{N}_{6}$ and $\mathrm{N}_{9}$ sites, whereas another $\mathrm{CH}_{3} \mathrm{Hg}^{+}$ion is coordinated via the $\mathrm{N}_{1}$ site forming ${ }_{1} \mathrm{D}$-chains. The other coordination mode was observed in $\left[\left(\mathrm{CH}_{3} \mathrm{Hg}\right)_{4}\right.$ (ade) $]\left(\mathrm{NO}_{3}\right) .55$ In this case, four $\mathrm{CH}_{3} \mathrm{Hg}^{+}$ions are linked by the $\mathrm{N}_{3}, \mathrm{~N}_{6}$ and $\mathrm{N}_{9}$ sites (Figure $4 \mathrm{j}$ ), creating a $2 \mathrm{D}$ structure.

Finally, adenine can also coordinate four metal ions via the $\mathrm{N}_{1}, \mathrm{~N}_{3}, \mathrm{~N}_{7}$ and $\mathrm{N}_{9}$ sites.56, 57 An example of this coordination mode was reported by $A n$ et al. (Figure $4 \mathrm{k}$ ) in $\left[\mathrm{Zn}_{8}(\text { ade })_{4}(\mathrm{BPDC}){ }_{6} \mathrm{O} \cdot 2 \mathrm{Me}_{2} \mathrm{NH}_{2}\right] \cdot 8 \mathrm{DMF} \cdot 11 \mathrm{H}_{2} \mathrm{O}$ (where BPDC = biphenyldicarboxylate; bio-MOF-1). ${ }^{17}$ In this structure, $\mathrm{Zn}(\mathrm{II})$ ions and adenine coordinate forming chains composed of apex-sharing octahedral cages. These chains are interconnected via multiple BPDC linkers, expanding the structure to a $3 \mathrm{D}$ porous network. 
Hydrochromic Behavior of 2. We observed that when 2 was heated at $150 \stackrel{\circ}{\circ} \mathrm{C}$, a new dehydrated phase, $\left[\mathrm{Co}_{2}\right.$ (ade) $\left.(\mathrm{BTeC})\left(\mathrm{H}_{2} \mathrm{O}\right)\right]$ (2'), was formed, as evidenced by comparing the TGA profiles of $\mathbf{2}$ and 2' (Figures $5 \mathrm{~b}$ ). During this transformation, the crystals of $\mathbf{2}$ were cracked and changed color from pink to purple (Figure 5a). This is thought to be due to the change in coordination of $\mathrm{Co \# 2}$, from octahedral to tetrahedral, which resulted from the loss of the coordinated $\mathrm{H}_{2} \mathrm{O}$ molecules. The UV/Vis spectra revealed a red shift in the d-d transition of the $\mathrm{Co}$ (II), from $\sim 515 \mathrm{~nm}$ (2) to $\sim 529 \mathrm{~nm}\left(\mathbf{2}^{\prime}\right)$, and the absorption band broadened (Figure $5 \mathrm{a}$ ). The sensitivity of these metal-based transitions to the geometry change, which occurs upon conversion of the $\mathrm{Co}$ (II) centers from six to mixed six/four coordination, is reminiscent of the color variations observed for other frameworks in which open transition metal sites

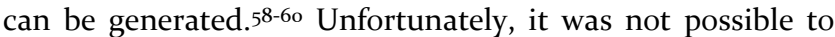
obtain more structural details of this transformation by determining the structure of 2' with single crystal X-ray diffraction, but its PXRD pattern showed loss of crystallinity to a high degree (Figure $5 \mathrm{c}$ ). This is indicative that structural re-arrangements occurred upon desolvation and that $\mathbf{2}$ is highly disordered.
In order to assess the porosity of 2' and check the influence of the structural re-arrangements upon desolvation, $\mathrm{N}_{2}$ and $\mathrm{CO}_{2}$ isotherms collected at $77 \mathrm{~K}$ and 195 $\mathrm{K}$, respectively, up to 1 bar (Figures S10, S11, ESI $\dagger$ ). 2' adsorbs very small amounts of $\mathrm{CO}_{2}\left(4.18 \mathrm{~cm}^{3} / \mathrm{g}\right.$ at 1 bar $)$ with a BET surface area of $8.11 \mathrm{~m}^{2} / \mathrm{g}$, and the $\mathrm{N}_{2}$ isotherm shows a characteristic type II shape confirming the non-porous behavior of 2'. This observation suggests that upon activation, dramatic structural changes occurred.

The structural changes observed between hydrated and dehydrated materials encouraged us to deeply analyzed this hydrochromic behavior. For this, we studied how 2 ' responds to the presence of liquid $\mathrm{H}_{2} \mathrm{O}$ and organic solvents. 2' was initially immersed in liquid $\mathrm{H}_{2} \mathrm{O}$ for different periods of time, and the evolution of the structure was monitored by PXRD and UV/Vis spectroscopy. Notably, after 24 hours, the purple color of 2' had changed to pink and the corresponding absorption band had blue-shifted to $515 \mathrm{~nm}$ (Figure 5a; Figure S8, ESI $\dagger$ ). The PXRD patterns showed an increase in crystallinity with time, which had stabilized after 2 days (Figure $5 \mathrm{c}$ ). After 3 days, both the main reflection at $2 \theta=$ 12. $0^{\circ}$ and the absorption band at $515 \mathrm{~nm}$, were essentially recovered compared with those observed for the newly synthesized 2 (Figures $5 \mathrm{a}-\mathrm{c}$ ). a.

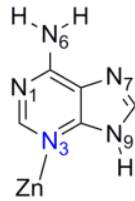

$\left[\mathrm{N}_{3}\right]$

García-Terán, 2004 [35]

b.

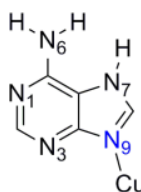

$\left[\mathrm{N}_{9}\right]$

García-Terán, 2006 [37]
C.

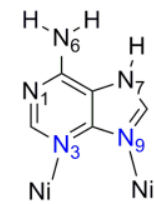

$\left[\mathrm{N}_{3}, \mathrm{~N}_{9}\right]$

Stylianou, 2011 [38]

1 [with $\mathrm{Co}(\mathrm{II})]$ d.

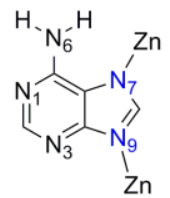

$\left[\mathrm{N}_{7}, \mathrm{~N}_{9}\right]$

Wang, 2011 [40] e.

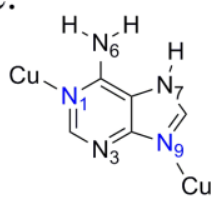

$\left[\mathrm{N}_{1}, \mathrm{~N}_{9}\right]$

Das, 2005 [43] f.

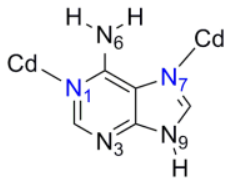

$\left[\mathrm{N}_{1}, \mathrm{~N}_{7}\right]$

Huang, 2012 [39] g.

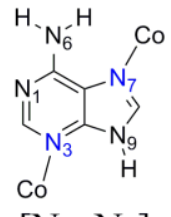

$\left[\mathrm{N}_{3}, \mathrm{~N}_{7}\right]$

2 h.<smiles></smiles>

$\left[\mathrm{N}_{3}, \mathrm{~N}_{7}, \mathrm{~N}_{9}\right]$ García-Terán, 2004 [46] i.

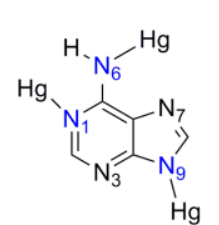

$\left[\mathrm{N}_{1}, \mathrm{~N}_{6}, \mathrm{~N}_{9}\right]$

Charland, 1987 [54] $\mathrm{j}$.

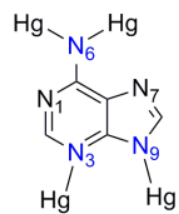

$\left[\mathrm{N}_{3}, \mathrm{~N}_{6}, \mathrm{~N}_{9}\right]$

Charland, 1986 [55] k.

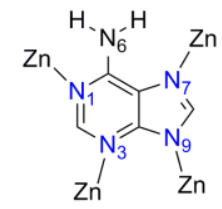

$\left[\mathrm{N}_{1}, \mathrm{~N}_{3}, \mathrm{~N}_{7}, \mathrm{~N}_{9}\right.$ ]

An, 2009 [17]

Figure 4. Representation of the coordination modes of adenine observed in extended structures. 
a.

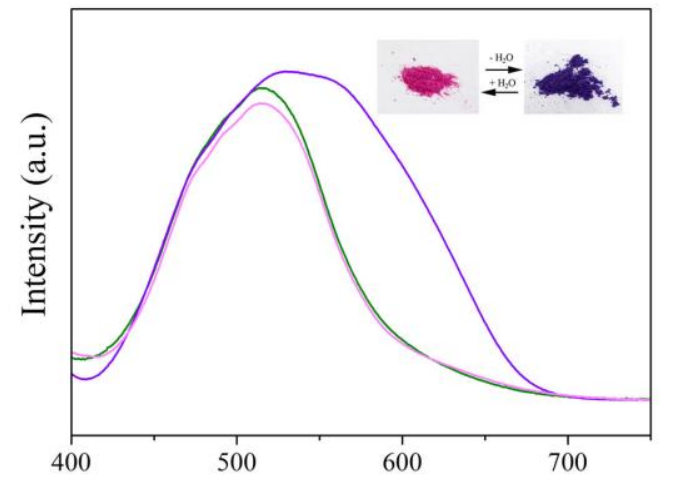

c.

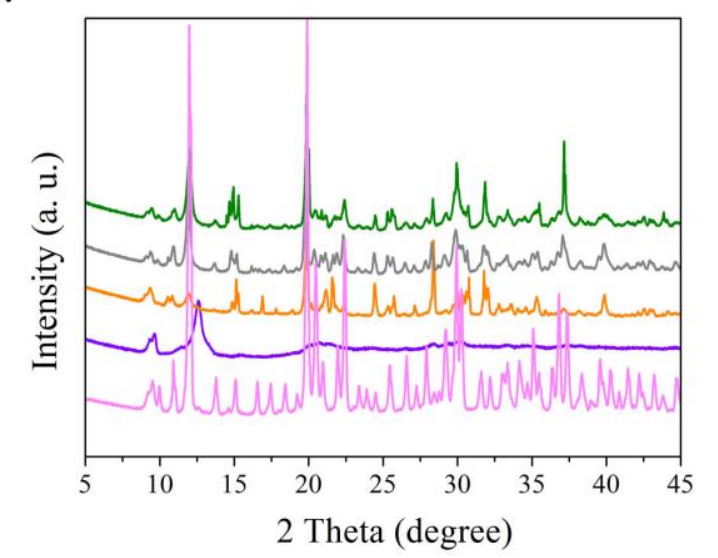

b.

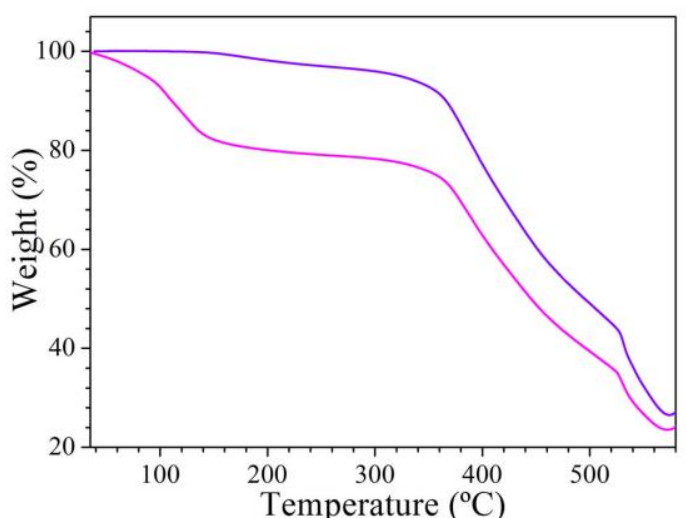

d.

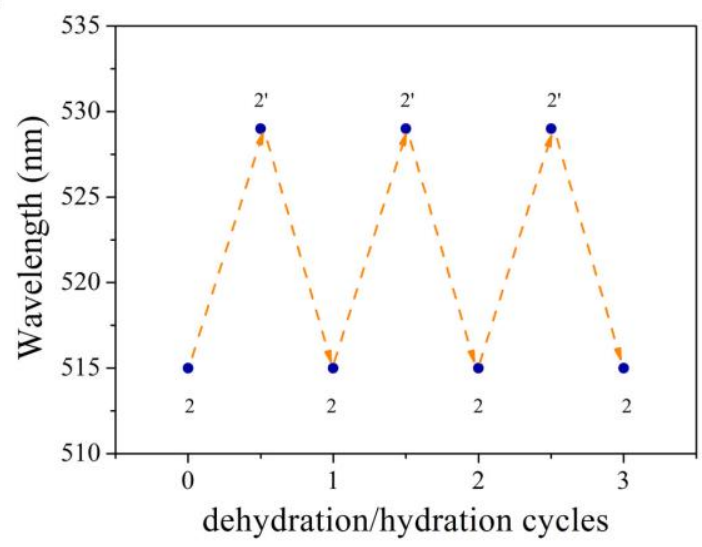

Figure 5. (a) UV/vis spectra of $\mathbf{2}$ (pink), $\mathbf{2}$ ' (purple) and regeneration of $\mathbf{2}$ after the immersion of $\mathbf{2}$ ' in liquid $\mathrm{H}_{2} \mathrm{O}$ (green). Inset: color change from pink (2) to purple ( $\left.\mathbf{2}^{\prime}\right)$ upon dehydration and hydration, (b) TGA diagrams of $\mathbf{2}$ (pink) and $\mathbf{2}^{\prime}$ (purple), (c) PXRD study showing the re-generation of $\mathbf{2}$ upon immersion of $\mathbf{2}$ ' in liquid $\mathrm{H}_{2} \mathrm{O}$ after three days: $\mathbf{2}$ (pink), $\mathbf{2}$ ' (purple) and 2 ' immersed in water for 1 day (orange), 2 days (grey) and 3 days (green), and (d) 2 can be activated and regenerated for at least three times as revealed by UV/vis spectroscopy retaining the comparable maximum absorption wavenumber (and also followed by the characteristic color change).

This recovery confirmed a large degree of reversibility for the $\mathrm{H}_{2} \mathrm{O}$-induced structural changes: the $\mathrm{H}_{2} \mathrm{O}$ molecules can coordinate to the Co\#2 center, regenerating its octahedral coordination geometry, and $\mathrm{H}_{2} \mathrm{O}$ molecules can diffuse within the structure, re-establishing the $\mathrm{H}$-bonds between them and the functional groups (mainly of the adenine), as evidenced by elemental analysis (ESI $\dagger$ ). The consistency and reversibility of these $\mathrm{H}_{2} \mathrm{O}$ - induced structural changes were confirmed by exposing a sample of 2 to three cycles of alternate dehydration (heating the sample at $150{ }^{\circ} \mathrm{C}$ for 30 minutes) and rehydration (soaking in $\mathrm{H}_{2} \mathrm{O}$ for 48 hours). Figure $5 \mathrm{~d}$ illustrates the alternating dehydration/hydration behavior measured in $\mathbf{2}$, with reversible absorption band shifts from $515 \mathrm{~nm}(\mathbf{2})$, to $529\left(\mathbf{2}^{\prime}\right)$. Based on this observation $\left(\mathrm{H}_{2} \mathrm{O}\right.$ importance for the recovery of $\left.\mathbf{2}\right)$, we checked if $\mathbf{2}$ could be recovered through the formation of these specific $\mathrm{H}$ bonding interactions between the framework with other polar and apolar solvents. Thus, the violet solid (2') was soaked in liquid methanol, ethanol, dimethylformamide, chloroform and hexane (Figure S9, ESI†). It is found that the violet color of 2' was retained after three days of treatment with all the solvents suggesting the well-organized structure of 2 was not formed. The PXRD of the methanol loaded sample confirmed that $\mathbf{2}$ cannot be recovered, indicating that the specific interactions between $\mathrm{H}_{2} \mathrm{O}$ molecules and host framework are key factors for retaining the structural integrity of $\mathbf{2 .}{ }^{12}$

\section{Conclusions}

In conclusion, we have prepared two new $3 \mathrm{D}$ CPs assembled from $\mathrm{Co}(\mathrm{II})$, adenine and aromatic tetracarboxylic acids. From a structural point of view, 1 shows a compact $3 \mathrm{D}$ binodal 4,6-c net with a new topology with the point symbol $\left\{4^{\wedge} 4 \cdot 6^{\wedge} 10.8\right\}\left\{4^{\wedge} 4 \cdot 6^{\wedge} 2\right\} .2$ shows a fsc net, in which adenine acts as a bidentate linker through a rare coordination mode; that is, through the $\mathrm{N}_{3}$ and $\mathrm{N}_{7}$ sites. In addition, 2 exhibits a clearly observable and reversible color change from pink (2) to purple ( $\left.\mathbf{2}^{\prime}\right)$, and vice versa, upon dehydration and hydration, respectively, indicative that structural rearrangements occurred upon activation. This has a direct impact on its sorption behavior as it is non porous to $\mathrm{CO}_{2}$ or $\mathrm{N}_{2}$. Contrawise, we found that $\mathrm{H}_{2} \mathrm{O}$ molecules can diffuse within the framework and organize the $3 \mathrm{D}$ open structure of 2. Selective structural recovery is likely driven by the reestablishment of the H-bonds occurred between $\mathrm{H}_{2} \mathrm{O}$ molecules and adenine in the host framework. 


\section{ASSOCIATED CONTENT}

\section{Supporting Information}

This material is available free of charge via the Internet at http://pubs.acs.org.

\section{AUTHOR INFORMATION}

\section{Corresponding Author}

E-mail: daniel.maspoch@icn.cat.

Funding Sources

This work was supported by the MINECO-Spain under the project PN MAT2012-30994.

\section{Notes}

The authors declare no competing financial interests.

\section{ACKNOWLEDGMENT}

I.B. thanks SENESCYT-Ecuador for a PhD fellowship. I.I. and K.C.S. are grateful to MINECO, for a Ramón y Cajal grant, and to the EU, for a Marie Curie Fellowship (300390 NanoBioMOFs $\mathrm{FP}_{7}$-PEOPLE-2011-IEF), respectively. ICN2 acknowledges support of the Spanish MINECO through the Severo Ochoa Centers of Excellence Program under Grant SEV-2013-0295.

\section{REFERENCES}

(1) Lin, X.; Telepeni, I.; Blake, A. J.; Dailly, A.; Brown, C. M.; Simmons, J. M.; Zoppi, M.; Walker, G. S.; Thomas, K. M.; Mays, T. J.; Hubberstey, P.; Champness, N. R.; Schroder, M., J. Am. Chem. Soc. 2009, 131, 2159-2171.

(2) Bux, H.; Feldhoff, A.; Cravillon, J.; Wiebcke, M.; Li, Y.-S.; Caro, J., Chem. Mater. 2011, 23, 2262-2269.

(3) Horike, S.; Dinca, M.; Tamaki, K.; Long, J. R., J. Am. Chem. Soc. 2008, 130, 5854-5855.

(4) Stylianou, K. C.; Heck, R.; Chong, S. Y.; Bacsa, J.; Jones, J. T. A.; Khimyak, Y. Z.; Bradshaw, D.; Rosseinsky, M. J., J. Am. Chem. Soc. 2010, 132, 4119-4130.

(5) Henninger, S. K.; Habib, H. A.; Janiak, C., J. Am. Chem. Soc. 2009, 131, 2776-2777.

(6) Britt, D.; Tranchemontagne, D.; Yaghi, O. M., Proc. Natl. Acad. Sci. U. S. A. 2008, 105, 11623-11627.

(7) Carné-Sánchez, A.; Bonnet, C. S.; Imaz, I.; Lorenzo, J.; Tóth, É.; Maspoch, D., J. Am. Chem. Soc. 2013, 135, 17711-17714.

(8) Horcajada, P.; Gref, R.; Baati, T.; Allan, P. K.; Maurin, G.; Couvreur, P.; Férey, G.; Morris, R. E.; Serre, C., Chem. Rev. 2011, 112, 1232-1268.

(9) Almeida Paz, F. A.; Klinowski, J.; Vilela, S. M. F.; Tome, J. P. C.; Cavaleiro, J. A. S.; Rocha, J., Chem. Soc. Rev. 2012, 41, $1088-1110$

(10) Couck, S.; Denayer, J. F. M.; Baron, G. V.; Remy, T.; Gascon, J.; Kapteijn, F., J. Am. Chem. Soc. 2009, 131, 6326-6327. (11) Rabone, J.; Yue, Y. F.; Chong, S. Y.; Stylianou, K. C.; Bacsa, J.; Bradshaw, D.; Darling, G. R.; Berry, N. G.; Khimyak, Y. Z.; Ganin, A. Y.; Wiper, P.; Claridge, J. B.; Rosseinsky, M. J., Science 2010, 329, 1053-1057.

(12) Gu, J.-Z.; Lu, W.-G.; Jiang, L.; Zhou, H.-C.; Lu, T.-B., Inorg. Chem. 2007, 46, 5835-5837.

(13) Imaz, I.; Rubio-Martinez, M.; An, J.; Sole-Font, I.; Rosi, N. L.; Maspoch, D., Chem. Commun. 2011, 47, 7287-7302.

(14) Šponer, J.; Leszczynski, J.; Hobza, P., Biopolymers 2001, 61, 3-31.

(15) Turecček, F.; Chen, X., J. Am. Soc. Mass. Spectrom. 2005, $16,1713-1726$.
(16) Beobide, G.; Castillo, O.; Cepeda, J.; Luque, A.; PérezYáñez, S.; Román, P.; Thomas-Gipson, J., Coord. Chem. Rev. 2013, 257, 2716-2736.

(17) An, J. Y.; Geib, S. J.; Rosi, N. L., J. Am. Chem. Soc. 2009, $131,8376-8377$.

(18) An, J.; Geib, S. J.; Rosi, N. L., J. Am. Chem. Soc. 2010, 132, 38-39.

(19) Murugavel, R.; Krishnamurthy, D.; Sathiyendiran, M., J. Chem. Soc., Dalton Trans. 2002, 1, 34-39.

(20) Beauvais, L. G.; Shores, M. P.; Long, J. R., J. Am. Chem. Soc. 2000, 122, 2763-2772.

(21) Yamada, M.; Sato, T.; Miyake, M.; Kobayashi, Y., J. Colloid Interface Sci. 2007, 315, 369-375.

(22) Uemura, K.; Kitagawa, S.; Kondo, M.; Fukui, K.; Kitaura, R.; Chang, H.-C.; Mizutani, T., Chem. - Eur. J. 2002, 8, 35863600 .

(23) Juanhuix, J.; Gil-Ortiz, F.;Cuní, G.; Colldelram, C.; Nicolás, J.; Lidón, J.; Boter, E.; Ruget, C.; Ferrer, S.; Benach, J., J. Synchrotron Radiat. 2014, 21, 679-689.

(24) Kabsch, W., Acta Crystallogr. Sect. D: Biol. Crystallogr. 2010, 66, 125-132.

(25) Leslie, A., Acta Crystallogr. Sect. D: Biol. Crystallogr. 2006, $62,48-57$.

(26) Siemens SAINT, 4; Siemens Analytical X-ray Instruments Inc.: Madison, Wisconsin, USA., 1996.

(27) Krause, L.; Herbst-Irmer, R.; Sheldrick, G. M.; Stalke, D., J. Appl. Crystallogr. 2015, 48, 3-10.

(28) Sheldrick, G. M.; Dauter, Z.; Wilson, K. S.; Hope, H.; Sieker, L. C., Acta Crystallogr. Sect. D: Biol. Crystallogr. 1993, 49, 18-23.

(29) Sheldrick, G., Acta Crystallogr. Sect. C: Cryst. Struct. Commun. 2015, 71, 3-8.

(30) Farrugia, L., J. Appl. Crystallogr. 2012, 45, 849-854.

(31) Blatov, V. A.; Shevchenko, A. P.; Proserpio, D. M., Crys. Growth Des. 2014, 14, 3576-3586.

(32) Coucouvanis, D.; Reynolds, R. A.; Dunham, W. R., J. Am. Chem. Soc. 1995, 117, 7570-7571.

(33) Aromí, G.; Batsanov, A. S.; Christian, P.; Helliwell, M.; Parkin, A.; Parsons, S.; Smith, A. A.; Timco, G. A.; Winpenny, R. E. P., Chem. - Eur. J. 2003, 9, 5142-5161.

(34) Spek, A. L., J. Appl. Crystallogr. 2003, 36, 7-13.

(35) García-Terán, J. P.; Castillo, O.; Luque, A.; García-Couceiro, U.; Román, P.; Lloret, F., Inorg. Chem. 2004, 43, 5761-5770.

(36) Pérez-Yáñez, S.; Castillo, O.; Cepeda, J.; García-Terán, J. P.; Luque, A.; Román, P., Inorg. Chim. Acta 2011, 365, 211-219.

(37) Garcia-Teran, J. P.; Castillo, O.; Luque, A.; Garcia-Couceiro, U.; Beobide, G.; Roman, P., Dalton Trans. 2006, 7, 902-911.

(38) Stylianou, K. C.; Warren, J. E.; Chong, S. Y.; Rabone, J.; Bacsa, J.; Bradshaw, D.; Rosseinsky, M. J., Chem. Commun. 2011, 47, 3389-3391.

(39) Huang, H.-X.; Tian, X.-Z.; Song, Y.-M.; Liao, Z.-W.; Sun, G.-M.; Luo, M.-B.; Liu, S.-J.; Xu, W.-Y.; Luo, F., Aust. J. Chem. 2012, 65, 320-325.

(40) Wang, F.; Tan, Y.-X.; Yang, H.; Zhang, H.-X.; Kang, Y.; Zhang, J., Chem. Commun. 2011, 47, 5828-5830.

(41) Paul, A. K.; Sanyal, U.; Natarajan, S., Crys. Growth Des. 2010, 10, 4161-4175.

(42) Wang, F.; Yang, H.; Kang, Y.; Zhang, J., J. Mater. Chem. 2012, 22, 19732-19737.

(43) Das, S.; Madhavaiah, C.; Verma, S.; Bharadwaj, P. K., Inorg. Chim. Acta 2005, 358, 3236-3240.

(44) Brandi-Blanco, M. d. P.; Choquesillo-Lazarte, D.; Domínguez-Martín, A.; Matilla-Hernández, A.; González-Pérez, J. M.; Castiñeiras, A.; Niclós-Gutiérrez, J., J. Inorg. Biochem. 2013, 127, 211-219.

(45) Bugella-Altamirano, E.; Choquesillo-Lazarte, D.; GonzálezPérez, J. M.; Sánchez-Moreno, M. J.; Marín-Sánchez, R.; Martín- 
Ramos, J. D.; Covelo, B.; Carballo, R.; Castiñeiras, A.; NiclósGutiérrez, J., Inorg. Chim. Acta 2002, 339, 160-170.

(46) García-Terán, J. P.; Castillo, O.; Luque, A.; García-Couceiro, U.; Román, P.; Lezama, L., Inorg. Chem. 2004, 43, 4549-4551.

(47) Li, T.; Chen, D.-L.; Sullivan, J. E.; Kozlowski, M. T.; Johnson, J. K.; Rosi, N. L., Chem. Sci. 2013, 4, 1746-1755.

(48) Hubert, J.; Beauchamp, A. L., Can. J. Chem. 1980, 58, 14391443.

(49) Charland, J.-P.; Britten, J. F.; Beauchamp, A. L., Inorg. Chim. Acta 1986, 124, 161-167.

(50) Pérez-Yáñez, S.; Beobide, G.; Castillo, O.; Cepeda, J.; Luque, A.; Aguayo, A. T.; Román, P., Inorg. Chem. 2011, 50, 5330-5332.

(51) Pérez-Yáñez, S.; Beobide, G.; Castillo, O.; Cepeda, J.; Luque, A.; Román, P., Cryst. Growth Des. 2012, 12, 3324-3334.

(52) Yang, E.-C.; Zhao, H.-K.; Ding, B.; Wang, X.-G.; Zhao, X.J., New J. Chem. 2007, 31, 1887-1890.

(53) Wang, F.; Kang, Y., Inorg. Chem. Commun. 2012, 20, 266268.

(54) Charland, J.-P., Inorg. Chim. Acta 1987, 135, 191-196.

(55) Charland, J. P.; Beauchamp, A. L., Inorg. Chem. 1986, 25, 4870-4876.

(56) Yang, E.-C.; Zhao, H.-K.; Feng, Y.; Zhao, X.-J., Inorg. Chem. 2009, 48, 3511-3513.

(57) An, J.; Farha, O. K.; Hupp, J. T.; Pohl, E.; Yeh, J. I.; Rosi, N. L., Nat Commun 2012, 3, 604.

(58) Uemura, K.; Kitagawa, S.; Kondo, M.; Fukui, K.; Kitaura, R.; Chang H.-C.; Mizutani, T., Chem. Eur. J. 2002, 8, 3587-3600.

(59) Rueff, J.-M.; Pillet, S.; Bonaventure, G.; Souhassou, M.; Rabu, P., Eur. J. Inorg. Chem. 2003, 4173-4178.

(60) Chen, Q.; Chang, Z.; Song, W.-C.; Song, H.; Hu, T.-L.; Bu, X.-H., Angew. Chem. Int. Ed. 2013, 52, 11550-11553. 


\section{Title: Two New Adenine-based Co(II) Coordination Polymers: Synthesis, Crystal Structure, Coordination Modes and Reversible Hydrochromic Behavior}

Authors: Iván Burneo, Kyriakos C. Stylianou, Sabina Rodríguez-Hermida, Jordi Juanhuix, Xavier Fontrodona, Inhar Imaz, and Daniel Maspoch
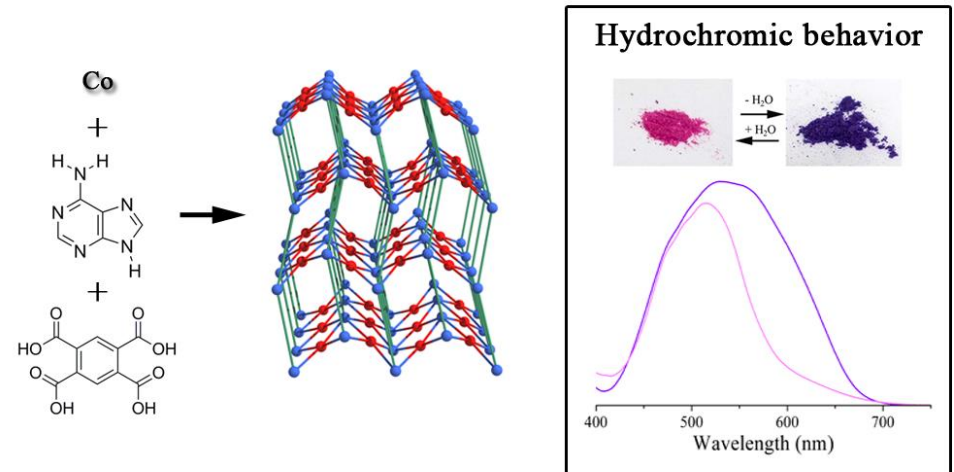

Two new 3D coordination polymers (CPs) based on Co(II), adenine and aromatic tetracarboxylate linkers and an analysis of the coordination modes of adenine found in extended coordination structures are reported. Interestingly, one of these CPs shows a reversible hydrochromic behavior, exhibiting a detectable colour change from pink to purple, and vice versa, upon hydration and dehydration, respectively. 